\title{
Trichospilus diatraeae (Hymenoptera: Eulophidae): development and reproduction in Lepidoptera palm oil pests
}

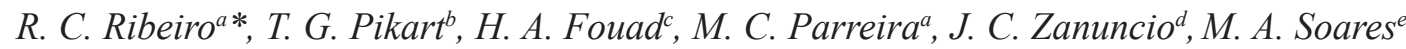 \\ and V.R. Castrof
}

aFaculdade de Agronomia, Universidade Federal do Pará - UFPA, Campus Universitário do Tocantins-Cametá, CEP 68400-000, Cametá, PA, Brasil

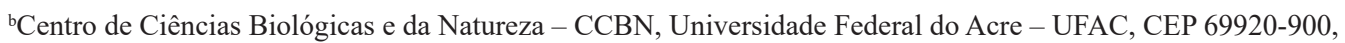
Rio Branco, AC, Brasil

${ }^{c}$ Faculty of Agriculture, Plant Protection Department, Sohag University, 82786, Sohag, Egypt

${ }^{d}$ Departamento de Entomologia - BIOAGRO, Universidade Federal de Viçosa - UFV, CEP 36570-900, Viçosa, MG, Brasil

'Programa de Pós-graduação em Produção Vegetal, Universidade Federal dos Vales Jequitinhonha e Mucuri - UFVJM, CEP 39100-000, Diamantina, MG, Brasil

fDepartamento de Engenharia Florestal, Universidade Federal de Viçosa - UFV, CEP 36570-900 Viçosa, MG, Brasil *e-mail: rribeiro@ufpa.br

Received: December 8, 2016 - Accepted: August 4, 2017 - Distributed: August 31, 2019

(With 2 figures)

\begin{abstract}
Brazil is a leading palm oil producer, but the defoliating caterpillars Opsiphanes invirae Hübner Brassolis sophorae L. (Lepidoptera: Nymphalidae) can reduce the productivity of this crop. The aim of this study was to evaluate the development and reproduction of the parasitoid Trichospilus diatraeae Cherian \& Margabandhu (Hymenoptera: Eulophidae) in pupae of these oil palm defoliators. Ten $O$. invirae or B. sophorae pupae with up to two days old were exposed each to $30 T$. diatraeae females for 48 hours. Parasitism and emergence of the progeny of $T$. diatraeae were similar in pupae of both Lepidoptera defoliators. The life cycle of this parasitoid was shorter in $O$. invirae ( $21.50 \pm 0.42$ days) pupae than with those of $B$. sophorae ( $27.60 \pm 1.80$ days). The number of the progeny $(669.00 \pm 89.62)$ and dead immature $(217.13 \pm 58.18)$ of $T$. diatraeae were higher in $B$. sophorae pupae than in those of $O$. invirae with $447.83 \pm 51.52$ and $13.50 \pm 5.23$, respectively. The sex ratio and female and male longevity of $T$. diatraeae emerged from these hosts were similar. The reproductive traits, especially the number of individuals (offspring) of $T$. diatraeae were better with $B$. sophorae pupae than with those of $O$. invirae.
\end{abstract}

Keywords: biological control, caterpillars defoliating, Elaeis guineensis, parasitoid.

\section{Trichospilus diatraeae (Hymenoptera: Eulophidae): desenvolvimento e reprodução em lepidópteros-praga da palma de óleo}

\section{Resumo}

O Brasil é um dos principais produtores de óleo de palma, porém as lagartas desfolhadoras Opsiphanes invirae Hübner e Brassolis sophorae L. (Lepidoptera: Nymphalidae) podem comprometer a produtividade dessa cultura. O objetivo deste trabalho foi avaliar o desenvolvimento e aspectos reprodutivos do parasitoide Trichospilus diatraeae Cherian \& Margabandhu (Hymenoptera: Eulophidae) em pupas desses desfolhadores da palma de óleo. Dez pupas de O. invirae ou de $B$. sophorae com até dois dias de idade, foram expostas, cada uma, ao parasitismo por 30 fêmeas de T. diatraeae, por 48 horas. O parasitismo e a emergência da progênie de $T$. diatraeae foram semelhantes em pupas de ambas as espécies de lepidópteros desfolhadores da palma de óleo. O ciclo de vida desse parasitoide foi mais curto em pupas de $O$. invirae (21,50 $\pm 0,42$ dias) que com as de $B$. sophorae $(27,60 \pm 1,80$ dias). O número de progênie $(669,00 \pm 89,62)$ e de imaturos mortos $(217,13 \pm 58,18)$ de $T$. diatraeae foram maiores em pupas de $B$. sophorae que naquelas de $O$. invirae com 447,83 $\pm 51,52$ e 13,50 $\pm 5,23$, respectivamente. A razão sexual e a longevidade de fêmeas e machos de $T$. diatraeae emergidos desses hospedeiros foram semelhantes. As características reprodutivas, especialmente, o número de indivíduos (progênie) de $T$. diatraeae foram melhores com pupas de $B$. sophorae que com as de $O$. invirae.

Palavras-chave: controle biológico, lagartas desfolhadoras, Elaeis guineensis, parasitoide. 


\section{Introduction}

The oil palm (Elaeis guineensis Jacq.) is of African origin and the main agro-industrial activity in humid areas in the Brazilian Amazon, Colombia, Ecuador, Malaysia, Indonesia and several African countries (Hansen et al., 2015). This culture is a source of vegetable oil for food production and Bio fuels with high profitability, employment generation fixing the man in the field and reduced environmental impacts (Thawaro and Te-chato, 2010; Abdalla et al., 2008). Elaeis guineensis is well adapted to the Amazon conditions with this region being that with the largest area in the world to expansing activity (Chia et al., 2009).

The Pará state is the largest palm oil producer in Brazil with an average productivity of six tonnes of oil/ha/year (Chia et al., 2009), but Lepidoptera defoliators as Opsiphanes invirae Hübner and Brassolis sophorae L. (Lepidoptera: Nymphalidae) can compromise this crop productivity (Ribeiro et al., 2010). The damage of Lepidoptera pests is incresead due to control measures deficiency without biological or synthetic chemical insecticides to be used against these pests (Ribeiro et al., 2010; Parra et al., 2009; Pereira et al., 2009a).

The natural biological control agents in palm tree crop in Brazil includes Chalcididae (Hymenoptera), Tachinidae and Sarcophagidae (Diptera) parasitizing Brassolis astyra Godart, B. sophorae, O. invirae and Opsiphanes sp. (Lepidoptera: Nymphalidae) larvae and pupae in the coconut (Cocus nucifera) (Marcicano et al., 2007, 2009) and oil palm (E. guineensis) (Tinôco et al., 2012) culture. This shows the importance of manipulating natural enemies to increase the biological control (Dobbs and Potter, 2016; Pereira et al., 2015; Smith et al., 2015).

Parasitic Hymenoptera can control insect pests, but the biology of these natural enemies in natural or alternative hosts must be understood (Boyd Júnior and Held, 2016). This is necessary because the host type can affect the oviposition rate, longevity, sex ratio, body size and fecundity (Silva-Torres et al., 2009) besides life history of natural enemies (Martins et al., 2016; Valente et al., 2016).

The pupal parasitoid Trichospilus diatraeae Cherian \& Margabandhu (Hymenoptera: Eulophidae) of Asian origin is gregarious, with polyphagous habit but with high prevalence in lepidopteran with its record in 1942 in the sugarcane borers, Diatraea venosata Walker (Lepidoptera: Pyralidae) (Bennett et al., 1987). This parasitoid has been studied for the biological control of pests in cucurbitaceous, eucalyptus, corn, pasture, soybean and sugar cane (Oliveira et al., 2016; Silva et al., 2015; Zaché et al., 2010).

This objective was to study the biology of the parasitoid T. diatraeae in the lepidopteran oil palm B. sophorae and O. invirae.

\section{Material and Methods}

This work was performed at the Agropalma Plant Complex in the municipality of Tailândia, Pará State, Amazon region of Brazil, 4850'30.57' (West longitude) and $02^{\circ} 34^{\prime} 37.51^{\prime \prime}$ (South latitude) in a room at $25 \pm 2{ }^{\circ} \mathrm{C}$, relative humidity of $70 \pm 10 \%$ and photophase of 12 hours.

\subsection{Rearing the alternative host}

Rearing Tenebrio molitor L. (Coleoptera: Curculionidae) started with larvae obtained from the Entomology Laboratory of Embrapa Eastern Amazon, Belém, Pará State. This host was kept in plastic trays $(39.3 \times 59.5 \times 7.0 \mathrm{~cm})$ in a room $\left(25 \pm 2{ }^{\circ} \mathrm{C}, 70 \pm 10 \%\right.$ $\mathrm{RH}$ and 12 hours photophase) with paper sheets covering the substrate of wheat bran where these insect laid eggs. Newly hatched T. molitor were fed wheat bran (97\%), yeast (3\%) and chayote slices as liquid supply until the adult emergence (Zanuncio et al., 2000).

\subsection{Rearing the parasitoid}

Adults of $T$. diatraeae were kept in glass tubes $(14.5 \times 2.0 \mathrm{~cm})$ plugged with cotton and with droplets of honey. The alternative host pupae T. molitor, up to 24 hours old, were exposed to parasitism for 48 hours at a temperature of $25 \pm 2{ }^{\circ} \mathrm{C}$, relative humidity of $70 \pm 10 \%$ and photophase of 12 hours followed by removal of the parasitoids (Pereira et al., 2009b).

\subsection{Collecting pest species}

Immature $O$. invirae and B. sophorae were collected in the field and transported to the laboratory of Agropalma, where they were placed in wooden cages $(50 \times 50 \times 70 \mathrm{~cm})$ and fed ad libitum with $E$. guineensis leaves until pupation.

\subsection{Bioassay}

Ten $O$. invirae and $B$. sophorae pupae weighing $1,500 \pm 90 \mathrm{mg}$ and $2,300 \pm 200 \mathrm{mg}$, respectively, and up to 48 hours at the pupa stage were used. These pupae were individualized in glass tubes $(14.5 \times 2.0 \mathrm{~cm})$ and exposed to parasitism by $30 \mathrm{~T}$. diatraeae females, which provide high fertility and parasitoid individuals with better morphological conditions (Ribeiro et al., 2010). These females were removed from the tubes after 48 hours of exposure to the hosts. The pupae and the female parasitoid density were determined in preliminary tests. These pupae were kept in a room at $25 \pm 2{ }^{\circ} \mathrm{C}$, $70 \pm 10 \% \mathrm{RH}$ and $12 \mathrm{~h}$ photophase until emergence of adult parasitoids or moths.

The duration of the life cycle (egg to adult), parasitism percentage, percentage and number of individuals emerged, sex ratio (number of females/total number of individuals), number of immature and parasitoid pupae that did not complete its development (host pupae were opened at forty days after parasitism and number of immature and dead parasitoid pupae counted) and the offspring longevity (males and females) were evaluated. The sex of $T$. diatraeae adults was determined by the morphological characteristics of the antenna and abdomen of this parasitoid (Paron, 1999).

\subsection{Statistical analysis}

The experiment was conducted in a randomized design with two treatments represented by the hosts $(O$. invirae and $B$. sophorae) parasitized by $T$. diatraeae with 10 replications, 
each with one host pupae. The percentage of parasitism and emergence of the progeny were subjected to nonparametric analysis of variance and when significant, compared with the Wilcoxon test at 5\% significance level. The data of cycle length, parasitoid number, immature dead, sex ratio and longevity of males and females $T$. diatraeae per host were tested using the $F 5 \%$ significance level (SAS Institute, 1997)

\section{Results}

Parasitism $(P=0.32)$ and emergency $(P=0.59)$ of T. diatraeae were similar in pupae of the two lepidopteran oil palm defoliator, with parasitism rates of $100 \%$ and $90 \%$ and the emergence of $60 \%$ and $50 \%$ from B. sophorae and $O$. invirae pupae, respectively (Figure 1).

The duration of egg-adult of $T$. diatraeae was shorter in $O$. invirae (21.50 \pm 0.42 days) pupae than in those B. sophorae $(27.60 \pm 1.80$ days $)(P=0.005)$ (Table 1 , Figure 2). Pupae of $B$. sophorae $(2,300 \pm 200 \mathrm{mg})$ were heavier than those of $O$. invirae $(1,500 \pm 90 \mathrm{mg})$.

The numbers of adults emerged $(P=0.04)$ and immature mortality $(P=0.01)$ of $T$. diatraeae were higher in $B$. sophorae pupae $(689.00 \pm 89.62$ and $217.13 \pm 58.18)$ than in those

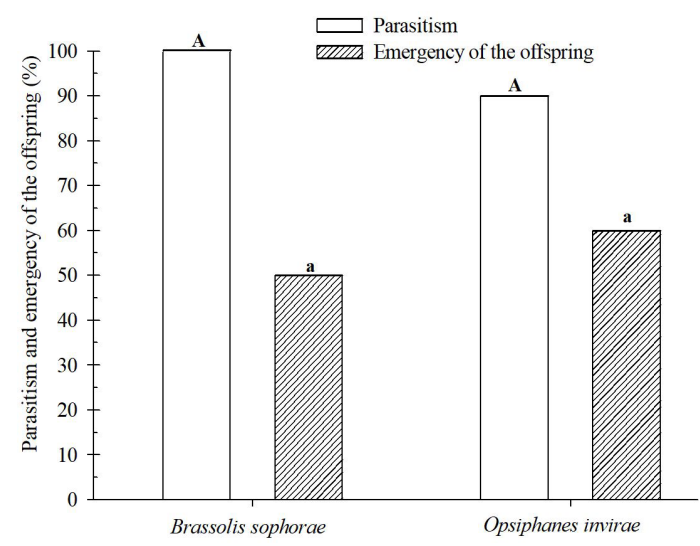

Figure 1. Parasitism and emergence (\%) of Trichospilus diatraeae (Hymenoptera: Eulophidae) in pupae of the Opsiphanes invirae Brassolis sophorae (Lepidoptera: Nymphalidae). Means followed by the same uppercase or lowercase letter do not differ by the nonparametric of Wilcoxon test $(\mathrm{p}<0.05)$. of $O$. invirae $(447.83 \pm 51.52$ and $13.50 \pm 5.23)$ (Table 1). The sex ratio $(P=0.29)$ and the longevity $(P=0.34)$ of males $(P=0.29) T$. diatraeae emerged from $B$. sophorae and $O$. invirae pupae were similar (Table 1$)$.

\section{Discussion}

The similar parasitism of $B$. sophorae and $O$. invirae pupae by $T$. diatraeae confirms the generalist habit of this parasitoid, as reported with Anticarsia gemmatalis Hübner, Heliothis virescens (Fabricius), Spodoptera frugiperda (Smith) (Noctuidae) and Diatraea saccharalis (Fabricius) (Pyralidae) (Paron and Berti-Filho, 2000), Thyrinteina arnobia (Stoll) (Geometridae) (Pereira et al., 2008) Tenebrio molitor L. (Tenebrionidae) (Favero, 2009) and Helicoverpa armigera pupae (Lepidoptera: Noctuidae) (Oliveira et al., 2016) pupae. Moreover, the similar percentage of emergence from $O$. invirae and $B$. sophorae pupae compared to $T$. diatraeae confirms the quality and/or nutritional values of these host to the parasitoid, because these factors can affect the onset and development of natural enemies (Brodeur and Boivin, 2004; Zanuncio et al., 2008).

The shortest duration from egg to adult $T$. diatraeae in $O$. invirae pupae than in those of B. sophorae can be attributed to the shorter pupa stage of the host, because the faster metabolism of the host can reduce the parasitoids

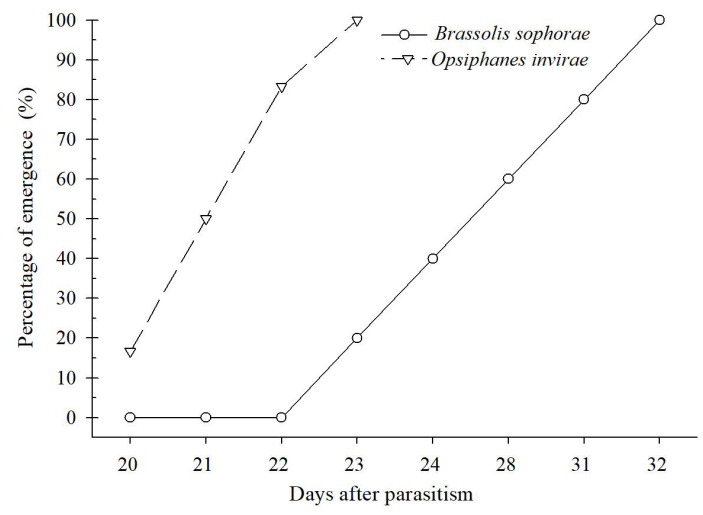

Figure 2. Accumulated percentage of Trichospilus diatraeae (Hymenoptera: Eulophidae) individuals emerged from Opsiphanes invirae and Brassolis sophorae (Lepidoptera: Nymphalidae) pupae.

Table 1. Cycle length (days), progeny, number of immature, sex ratio, longevity (days) for males and females (mean \pm standard error) of Trichospilus diatraeae (Hymenoptera: Eulophidae) in pupae of Lepidoptera palm oil defoliators.

\begin{tabular}{lcccc}
\hline \multicolumn{1}{c}{ Biological characteristics } & Opsiphanes invirae & N & Brassolis sophorae & N \\
\hline Egg - adult (days) & $21.50 \pm 0.42 \mathrm{~b}$ & 6 & $27.60 \pm 1.80 \mathrm{a}$ & 5 \\
Progeny & $447.8 \pm 51.5 \mathrm{~b}$ & 6 & $669.0 \pm 89.6 \mathrm{a}$ & 5 \\
Number of immature dead & $13.5 \pm 5.23 \mathrm{~b}$ & 6 & $217.1 \pm 58.2 \mathrm{a}$ & 8 \\
Sex ratio & $0.95 \pm 0.01 \mathrm{a}$ & 6 & $0.97 \pm 0.01 \mathrm{a}$ & 5 \\
Longevity of females (days) & $9.95 \pm 1.25 \mathrm{a}$ & 20 & $12.0 \pm 1.76 \mathrm{a}$ & 20 \\
Longevity of males (days) & $9.0 \pm 1.35 \mathrm{a}$ & 10 & $7.3 \pm 0.70 \mathrm{a}$ & 10 \\
\hline
\end{tabular}

Means followed by the same letter per line do not differ by the F test $(p<0.05)$. 
cycle. The solitary endoparasitoid Meteorus gyrator (Thunberg) (Hymenoptera: Braconidae) had shorter duration of the larval stage with Chrysodeixis chalcites (Esper) (Lepidoptera: Noctuidae) than with four other Noctuidae species, due to increased host speed development (C. chalcites) (Smethurst et al., 2004). Moreover, competition among immature $T$. diatraeae in the smaller $O$. invirae pupae and consequently the lower food resources available compared to larger $B$. sophorae pupae may also resulted in the development duration in that host (Aruna and Manjunath, 2010). The longest duration of $T$. diatraeae development in $B$. sophorae pupae can reduce the chances of host survival by it increases the period vulnerable to predators, pathogens or the host response (Benrey and Denno, 1997).

The larger T. diatraeae progeny in B. sophorae pupae that in those of $O$. invirae demonstrates a better quality of the first host for this parasitoid reproduction, what was helped by the greater pupae (Fidgen et al., 2000; Brodeur and Boivin 2004, Silva-Torres et al., 2009). Parasitoid females usually oviposit more eggs on larger hosts known as a principle of sex allocation (Jones, 1982), by having more food for immature stages (Uçkan et al., 2004). However, the immune defense of larger host can affect the development and survival of immature parasitoids (Strand and Pech, 1995; Andrade et al., 2010). The resource explored by immature $T$. diatraeae was similar in each host with $3.43 \mathrm{mg}$ of fresh weight in B. sophorae [mean pupae weight $(2,300 \pm 200 \mathrm{mg}) /$ average number of progeny emerged (669.0 \pm 89.6$)$ ] and $3.35 \mathrm{mg}$ wet weight in pupae of $O$. invirae [weight $(1,500 \pm 90 \mathrm{mg}) /$ average number of progeny emerged $(447.8 \pm 51.5)]$ to produce each parasitoid adult. This confirms the hypothesis that host nutritional quality regulates the size of the population of T. diatraeae (Zaviezo and Mills, 2000; Bell et al., 2005). However, this differs from that observed for Hyssopus pallidus Askew (Hymenoptera, Eulophidae), where each milligram of wet weight of Cydia molesta Busck (lower host) produced $0.82 \pm 3.8$ and the same parasitoid of C. pomonella L. (Lepidoptera: Tortricidae) (bigger host) was able to produce only $0.27 \pm 0.18$ this parasitoid, showing nutritional quality between these different hosts (Häckermann et al., 2007).

The high number of immature dead in dissected $B$. sophorae pupae may be due to host immune defenses (Andrade et al., 2010) and/or the excessive egg numbers laid by $T$. diatraeae per host pupae (Jones, 1982). Competition among parasitoid larvae in the host can cause mortality and reduce the number of adults of these parasitoids emerged (Chong and Oetting, 2007).

A similarly high sex ratio of $T$. diatraeae in the lepidopteran $B$. sophorae and $O$. invirae pupae agrees with that reported for the parasitoid Palmistichus elaeisis Delvare \& LaSalle (Hymenoptera: Eulophidae) in Bombyx mori L. (Lepidoptera: Bombycidae) pupae (Pereira et al., 2009a). This may be an Eulophidae (Pereira et al., 2010) and Ichneumonidae (Matos Neto et al., 2004) characteristic, facilitating these parasitoids to increase their populations in the laboratory and field (Matos Neto et al., 2005; Amalin et al., 2005). Furthermore, it indicates a high potential reproductive capacity of $T$. diatraeae for integrated management of Lepidoptera oil palm defoliators.

A similar longevity of $T$. diatraeae males and females emerged from $B$. sophorae or $O$. invirae pupae indicates an adequate nutritional quality of these hosts, which can affect adult parasitoids (males and females) during its immature stage (Brodeur and Boivin, 2004). The parasitoid T. diatraeae has the potential for the biological control of Lepidoptera oil palm defoliators, especially, B. sophorae.

\section{Acknowledgements}

We thank the Brazilian agencies "Conselho Nacional de Desenvolvimento Cientifico e Tecnológico (CNPq), Coordenação de Aperfeiçoamento de Pessoal de Nível Superior (CAPES/PELD), Fundação de Amparo à Pesquisa do Estado de Minas Gerais (FAPEMIG)," and "Programa Cooperativo sobre Proteção Florestal/ PROTEF" of the "Instituto de Pesquisas e Estudos Florestais/IPEF" for scholarships and financial support.

\section{References}

ABDALLA, A.L., SILVA FILHO, J.C., GODÓI, A., CARMO, C.A. and EDUARDO, J.L.P., 2008. Utilização de subprodutos da indústria de biodiesel na alimentação de ruminantes. Revista Brasileira de Zootecnia, vol. 37, no. spe, pp. 260-258. http:// dx.doi.org/10.1590/S1516-35982008001300030.

AMALIN, D.M., PENA, J.E. and DUNCAN, R.E., 2005. Effects of host age, female parasitoid age, and host plant on parasitism of Ceratogramma etiennei (Hymenoptera: Trichogrammatidae). The Florida Entomologist, vol. 88, no. 1, pp. 77-82. http://dx.doi. org/10.1653/0015-4040(2005)088[0077:EOHAFP]2.0.CO;2.

ANDRADE, G.S., SERRÃO, J.E., ZANUNCIO, J.C., ZANUNCIO, T.V., LEITE, G.L.D. and POLANCZYK, R.A., 2010. Immunity of an alternative host can be overcome by higher densities of its parasitoids Palmistichus elaeisis and Trichospilus diatraeae. PLoS One, vol. 5, no. 10, pp. 13231. http://dx.doi.org/10.1371/ journal.pone.0013231. PMid:20975929.

ARUNA, A.S. and MANJUNATH, D., 2010. Reproductive performance of Nesolynx thymus (Hymenoptera: Eulophidae) as influenced by host (Musca domestica) size. BioControl, vol. 55, no. 2, pp. 245-252. http://dx.doi.org/10.1007/s10526-009-9256-3.

BELL, H.A., MARRIS, G.C., PRICKETT, A.J. and EDWARDS, J.P., 2005. Influence of host size on the clutch size and developmental success of the gregarious ectoparasitoid Eulophus pennicornis (Nees) (Hymenoptera: Braconidae) attacking larvae of the tomato moth Lacanobia oleracea (L.) (Lepidoptera: Noctuidae). The Journal of Experimental Biology, vol. 208, no. Pt 16, pp. 3199 3209. http://dx.doi.org/10.1242/jeb.01759. PMid:16081616.

BENNETT, F.D., GLENN, H., YASEEN, M. and BARANOWSKI, R.M., 1987. Records of Trichospilus diatraeae, an Asian parasite (Hymenoptera: Eulophidae) from the Caribbean and Florida. The Florida Entomologist, vol. 70, no. 1, pp. 184-186. http://dx.doi. org/10.2307/3495110.

BENREY, B. and DENNO, R.F., 1997. The slow-growth-highmortality hypothesis: a test using the cabbage butterfly. Ecology, vol. 78, pp. 987-999. 
BOYD JÚNIOR, D.W. and HELD, D.W., 2016. Development of Thripastichus gentilei (Hymenoptera: Eulophidae) in the thrips Gynaikothrips uzeli (Thysanoptera: Phlaeothripidae). The Florida Entomologist, vol. 99, no. 3, pp. 440-444. http://dx.doi. org/10.1653/024.099.0315.

BRODEUR, J. and BOIVIN, G., 2004. Functional ecology of immature parasitoids. Annual Review of Entomology, vol. 49, no. 1, pp. 27-49. http://dx.doi.org/10.1146/annurev.ento.49.061703.153618. PMid:14651455.

CHIA, G.S., LOPES, R., CUNHA, R.N.V., ROCHA, R.N.C. and LOPES, M.T.G., 2009. Repetibilidade da produção de cachos de híbridos interespecíficos entre o caiaué e o dendezeiro. Acta Amazonica, vol. 39, no. 2, pp. 249-254. http://dx.doi.org/10.1590/ S0044-59672009000200001.

CHONG, J.H. and OETTING, R.D., 2007. Progeny fitness of the mealybug parasitoid Anagyrus sp. nov. nr. sinope (Hymenoptera: Encyrtidae) as affected by brood size, sex ratio, and host quality. The Florida Entomologist, vol. 90, no. 4, pp. 656-664. http:// dx.doi.org/10.1653/0015-4040(2007)90[656:PFOTMP]2.0.CO;2.

DOBBS, E.K. and POTTER, D.A., 2016. Naturalized habitat on golf courses: source or sink for natural enemies and conservation biological control? Urban Ecosystems, vol. 19, no. 2, pp. 899-914. http://dx.doi.org/10.1007/s11252-015-0521-1.

FÁVERO, K., 2009. Biologia e técnicas de criação de Trichospilus diatraeae (Hymenoptera: Eulophidae) em pupas de Tenebrio molitor (Coleoptera: Tenebrionidae) e Diatraea saccharalis (Lepidoptera: Crambidae). Dourados: Universidade Federal da Grande Dourados, 77 p. Mestrado em Entomologia e Conservação da Biodiversidade.

FIDGEN, J.G., EVELEIGH, E.S. and QUIRING, D.T., 2000. Influence of host size on oviposition behaviour and fitness of Elachertus cacoeciae attacking a low-density population of spruce budworm Choristoneura fumiferana larvae. Ecological Entomology, vol. 25 , no. 2 , pp. 156-164. http://dx.doi.org/10.1046/j.13652311.2000.00248.x.

HÄCKERMANN, J., ROTT, A.S. and DORN, S., 2007. How two different host species influence the performance of a gregarious parasitoid: host size is not equal to host quality. Journal of Animal Ecology, vol. 76, no. 2, pp. 376-383. http:// dx.doi.org/10.1111/j.1365-2656.2006.01206.x. PMid:17302845.

HANSEN, S.B., PADFIELD, R., SYAYUTI, K., EVERS, S., ZAKARIAH, Z. and MASTURA, S., 2015. Trends in global palm oil sustainability research. Journal of Cleaner Production, vol. 100, pp. 140-149. http://dx.doi.org/10.1016/j.jclepro.2015.03.051.

JONES, W.T., 1982. Sex ratio and host size in a parasitoid wasp. Behavioral Ecology and Sociobiology, vol. 10, no. 3, pp. 207-210. http://dx.doi.org/10.1007/BF00299686.

MARCICANO, M.D., NIHEI, S.S. and LIMA, I.M.M., 2009. First host record for Winthemia analis (Macquart) (Diptera: Tachinidae: Exoristinae) in Brazil: Brassolis sophorae laurentii Stichel (Lepidoptera: Nymphalidae: Brassolinae). Neotropical Entomology, vol. 38, no. 4, pp. 550-552. http://dx.doi.org/10.1590/ S1519-566X2009000400020. PMid:19768279.

MARCICANO, M.-D.L., LIMA, I.M.M., TAVARES, M.T. and CASAGRANDE, M.M., 2007. Parasitism of Brassolis sophorae laurentii Stichel (Lepidoptera: Nymphalidae, Brassolinae) pupae by Conura morleyi (Ashmead) (Hymenoptera: Chalcididae, Chalcidini), in the State of Alagoas, Brazil. Neotropical Entomology, vol. 36, no. 4, pp. 629-631. http://dx.doi.org/10.1590/S1519566X2007000400026. PMid:17934634.
MARTINS, A.L., GALLÃO, J.E., BICHUETTE, M.E. and SANTOS, E.F., 2016. The first record of Notocyphus tyrannicus Smith, (Hymenoptera: Pompilidae) as parasitoid of Acanthoscurria Ausserer, 1871 (Teraphosidae: Teraphosinae). Brazilian Journal of Biology $=$ Revista Brasileira de Biologia, vol. 76, no. 3, pp. 806807. http://dx.doi.org/10.1590/1519-6984.07515. PMid:27143057.

MATOS NETO, F.C., CRUZ, I., ZANUNCIO, J.C., SILVA, C.H.O. and PICANÇO, M.C., 2004. Parasitism by Campoletis flavicincta on Spodoptera frugiperda in corn. Pesquisa Agropecuária Brasileira, vol. 39, no. 11, pp. 1077-1081. http://dx.doi.org/10.1590/ S0100-204X2004001100004.

MATOS NETO, F.C., ZANUNCIO, J.C., CRUZ, I., GUEDES, R.N.C. and PICANÇO, M.C., 2005. Progeny production and parasitism by Campoletis flavicincta (Hym. Ichneumonidae) as affected by female ageing. Biological Agriculture and Horticulture, vol. 22 , no. 4 , pp. 369-378. http://dx.doi.org/10.1080/0144876 5.2005 .9755298

OLIVEIRA, H.N., SIMONATO, J., GLAESER, D.F. and PEREIRA, F.F., 2016. Parasitism of Helicoverpa armigera pupae (Lepidoptera: Noctuidae) by Tetrastichus howardi and Trichospilus diatraeae (Hymenoptera: Eulophidae). Semina: Ciências Agrárias, vol. 37, no. 1, pp. 111-115. http://dx.doi. org/10.5433/1679-0359.2016v37n1p111

PARON, M.R. 1999. Bioecologia de Trichospilus diatraeae Cherian \& Maragabandhu, 1942 (Hymenoptera: Eulophidae), endoparasitóide de Lepidoptera. Piracicaba: Escola Superior "Luis de Queiroz, Universidade de São Paulo, 63 p. Tese de Doutorado em Entomologia.

PARON, M.R. and BERTI FILHO, E., 2000. Capacidade reprodutiva de Trichospilus diatraeae (Hymenoptera: Eulophidae) em pupas de diferentes hospedeiros (Lepidoptera). Scientia Agrícola, vol. 57, no. 2, pp. 355-358. http://dx.doi.org/10.1590/ S0103-90162000000200025.

PARRA, E., PEÑA, J., ESPARZA, D. and LABARCA, M., 2009. Evaluación de sustratos orgánicos y en combinación con insecticida para la captura de adultos de Opsiphanes cassina Felder en una plantación de palma aceitera (Elaeis guineensis Jacquin.) en el estado Zulia, Venezuela. Revista de la Facultad de Agronomía, Universidad del Zulia, vol. 26, pp. 455-469.

PEREIRA, A.G., SILVA, R.B., DIAS, M.M. and PENTEADODIAS, A.M., 2015. Study on the Hymenoptera parasitoid associated with Lepidoptera larvae in reforestation and agrosilvopastoral systems at Fazenda Canchim (Embrapa Pecuaria Sudeste) Sao Carlos, SP, Brazil. Brazilian Journal of Biology = Revista Brasileira de Biologia, vol. 75, no. 4, pp. 783-789. http://dx.doi. org/10.1590/1519-6984.21913. PMid:26602340.

PEREIRA, F.F., ZANUNCIO, J.C., SERRÃO, J.E., PASTORI, P.L. and RAMALHO, F.S., 2009a. Reproductive performance of Palmistichus elaeisis (Hymenoptera: Eulophidae) with previously refrigerated pupae of Bombyx mori (Lepidoptera: Bombycidae). Brazilian Journal of Biology $=$ Revista Brasileira de Biologia, vol. 69, no. 3, pp. 631-637. http://dx.doi.org/10.1590/S151969842009000400014. PMid:19802446.

PEREIRA, F.F., ZANUNCIO, J.C., SERRÃO, J.E., OLIVEIRA, H.N., FÁVERO, K. and GRANCE, E.L.V., 2009b. Progênie de Palmistichus elaeisis Delvare \& LaSalle (Hymenoptera: Eulophidae) parasitando pupas de Bombyx mori L. (Lepidoptera: Bombycidae) de diferentes idades. Neotropical Entomology, vol. 38, no. 5, pp. 660-664. http://dx.doi.org/10.1590/S1519-566X2009000500016. PMid:19943016. 
PEREIRA, F.F., ZANUNCIO, J.C., SERRÃO, J.E., ZANUNCIO, T.V., PRATISSOLI, D. and PASTORI, P.L., 2010. The density of females of Palmistichus elaeisis Delvare and LaSalle (Hymenoptera: Eulophidae) affects their reproductive performance on pupae of Bombyx mori L. (Lepidoptera: Bombycidae). Anais da Academia Brasileira de Ciências, vol. 82, no. 2, pp. 323-331. http://dx.doi. org/10.1590/S0001-37652010000200008. PMid:20563413.

PEREIRA, F.F., ZANUNCIO, J.C., TAVARES, M.T., PASTORI, P.L., JACQUES, G.C. and VILELA, E.F., 2008. New record of Trichospilus diatraeae as a parasitoid of the eucalypt defoliator Thyrinteina arnobia in Brazil. Phytoparasitica, vol. 36, no. 3, pp. 304-306. http://dx.doi.org/10.1007/BF02980777.

RIBEIRO, R.C., LEMOS, W.P., BERNARDINO, A.S., BUECKE, J. and MÜLLER, A.A., 2010. Primeira ocorrência de Alcaeorrhynchus grandis (Dallas) (Hemiptera: Pentatomidae) predando lagartas desfolhadoras do dendezeiro no Estado do Pará. Neotropical Entomology, vol. 39, no. 1, pp. 131-132. http://dx.doi. org/10.1590/S1519-566X2010000100018. PMid:20305909.

SAS INSTITUTE, 1997. User `s guide: statistics. Cary: SAS Institute.

SILVA, I.M., ZANUNCIO, T.V., PEREIRA, F.F., WILCKEN, C.F., SERRÃO, J.E. and ZANUNCIO, J.C., 2015. Reproduction of Trichospilus diatraeae (Hymenoptera: Eulophidae) in the pupae of Diaphania hyalinata (Lepidoptera: Crambidae) of various ages. The Florida Entomologist, vol. 98, no. 4, pp. 1025-1029. http:// dx.doi.org/10.1653/024.098.0403.

SILVA-TORRES, C.S.A., RAMOS FILHO, I., TORRES, J.B. and BARROS, R., 2009. Superparasitism and host size effects in Oomyzus sokolowskii, a parasitoid of diamondback moth. Entomologia Experimentalis et Applicata, vol. 33, no. 1, pp. 65-73. http://dx.doi.org/10.1111/j.1570-7458.2009.00903.x.

SMETHURST, F., BELL, H.A., MATTHEWS, H.J. and EDWARDS, J.P., 2004. The comparative biology of the solitary endoparasitoid Meteorus gyrator (Hymenoptera: Braconidae) on five noctuid pest species. European Journal of Entomology, vol. 101, no. 1, pp. 75-81. http://dx.doi.org/10.14411/eje.2004.016.

SMITH, I.M., HOFFMANN, A.A. and THOMSON, L.J., 2015. Coccinellid abundance in shelterbelts is affected more by adjacent crop type and aphid abundance than vegetation characteristics. Biological Control, vol. 87, pp. 47-55. http://dx.doi.org/10.1016/j. biocontrol.2015.04.004.

STRAND, M.R. and PECH, L.L., 1995. Immunological basis for compatibility in parasitoid-host relationships. Annual Review of Entomology, vol. 40, no. 1, pp. 31-56. http://dx.doi.org/10.1146/ annurev.en.40.010195.000335. PMid:7810989.
THAWARO, S. and TE-CHATO, S., 2010. Effect of culture medium and genotype on germination of hybrid oil palm zygotic embryos. ScienceAsia, vol. 36, no. 1, pp. 26-32. http://dx.doi. org/10.2306/scienceasia1513-1874.2010.36.026.

TINÔCO, R.S., RIBEIRO, R.C., TAVARES, M.T., VILELA, E.F., LEMOS, W.P. and ZANUNCIO, J.C., 2012. Brachymeria spp. (Hymenoptera: Chalcididae) parasitizing pupae of Hesperidae and Nymphalidae (Lepidoptera) pests of oil palm in the Brazilian Amazonian region. The Florida Entomologist, vol. 95, no. 3, pp. 788-789. http://dx.doi.org/10.1653/024.095.0335.

UÇKAN, F., ERGIN, E. and AYAZ, F., 2004. Modeling age- and density structured reproductive biology and seasonal survival of Apanteles galleriae Wilkinson (Hym., Braconidae). Journal of Applied Entomology, vol. 128, no. 6, pp. 407-413. http://dx.doi. org/10.1111/j.1439-0418.2004.00864.x.

VALENTE, E.C.N., BROGLIO, S.M.F., PASSOS, E.M. and DE LIMA, A.S.T. 2016. Performance of Trichogramma galloi (Hymenoptera: Trichogrammatidae) on eggs of Diatraea spp. (Lepidoptera: Crambidae). Pesquisa Agropecuária Brasileira, vol. 51, no. 4, pp. 293-300.

ZACHÉ, B., WILCKEN, C.F., DACOSTA, R.R. and SOLIMAN, E.P., 2010. Trichospilus diatraeae Cherian \& Margabandhu, 1942 (Hymenoptera: Eulophidae), a new parasitoid of Melanolophia consimilaria (Lepidoptera: Geometridae). Phytoparasitica, vol. 38, no. 4, pp. 355-357. http://dx.doi.org/10.1007/s12600-010-0108-6.

ZANUNCIO, J.C., PEREIRA, F.F., JACQUES, G.C., TAVARES, M.T. and SERRÃO, J.E., 2008. Tenebrio molitor Delvare \& LaSalle (Coleoptera: Tenebrionidae), a new alternative host to rear the pupae parasitoid Palmistichus elaeisis (Hymenoptera: Eulophidae). Coleopterists Bulletin, vol. 62, pp. 64-66. http:// dx.doi.org/10.1649/1015.1.

ZANUNCIO, J.C., ZANUNCIO, T.V., GUEDES, R.N.C. and RAMALHO, F.S., 2000. Effect of feeding on three Eucalyptus species on the development of Brontocoris tabidus (Het.: Pentatomidae) fed with Tenebrio molitor (Col.: Tenebrionidae). Biocontrol Science and Technology, vol. 10, no. 4, pp. 443-450. http://dx.doi.org/10.1080/09583150050115025.

ZAVIEZO, T. and MILLS, N., 2000. Factors influencing the evolution of clutch size in a gregarious insect parasitoid. Journal of Animal Ecology, vol. 69, no. 6, pp. 1047-1057. http://dx.doi. org/10.1046/j.1365-2656.2000.00460.x. 